\title{
ECONOMY
}

\section{COMPULSORY HEALTH INSURANCE AS ONE OF THE MECHANISMS OF ENSURING PUBLIC HEALTH}

\author{
Huseynova Saida Ramis \\ The Republic of Azerbaijan, Baku, Lecturer in Azerbaijan State Economic Univestity
}

DOI: https://doi.org/10.31435/rsglobal_wos/30122019/6842

\section{ARTICLE INFO}

Received: 26 October 2019

Accepted: 19 December 2019

Published: 30 December 2019

\section{KEYWORDS}

healthcare,

compulsory insurance,

Azerbaijan,

law,

finance. \begin{abstract}
Insurance relations are one of the most important elements of the market relations system. In the context of market relations, the principles of insurance, formation of the insurance market and the expansion of insurance services are important factors.

The study was aimed to determine the ways of attracting resources for the protection, strengthening and provision of health care of population by the means of health insurance.

Furthermore, the value and quality of resources allocated by both state and other market players, and the effectiveness of their use in the health sector have been analyzed.

In this regard, the author has conducted analyze of key health indicators and also examined healthcare financing system of different countries.

The mechanism of applying compulsory health insurance in Azerbaijan as a pilot project and the project's outcomes were taken into consideration while conducting a research.
\end{abstract}

Citation: Huseynova Saida Ramis. (2019) Compulsory Health Insurance as One of the Mechanisms of Ensuring Public Health. International Academy Journal Web of Scholar. 12(42). doi: 10.31435/rsglobal_wos/30122019/6842

Copyright: (C) 2019 Huseynova Saida Ramis. This is an open-access article distributed under the terms of the Creative Commons Attribution License (CC BY). The use, distribution or reproduction in other forums is permitted, provided the original author(s) or licensor are credited and that the original publication in this journal is cited, in accordance with accepted academic practice. No use, distribution or reproduction is permitted which does not comply with these terms.

Purpose of the study. The purpose of the research is to identify the mechanism of implementation compulsory health insurance in Azerbaijan and to learn different approachs of establishing insurance funds. For this purpose, the article has explored pivotal foreign practice, certain indicators of different countries.

Introduction. Health insurance is one of the key elements of the system of social protection of population, protection of health and obtaining the necessary medical care in case of illness.

The way of attracting economic resources for the protection, strengthening and provision of health care for the population is a historic process. The value and quality of resources allocated by both state and other market players, and the effectiveness of their use in the health sector, is determined by the economic, political and other complexity of relations in the country.

The sustainability of health systems in different countries is determined by the state's role within the country.

To look in history, you can see that health insurance, especially compulsory insurance, in its modern form has already emerged in the early 20th century in Germany, England, Russia and some other countries [1].

Currently, health insurance systems are built on three major economic models [2]: a German model with a multi-channel financing mechanism for market management, the English economist William Beveric's budget-based public health system (some researchers also refer Nikolai Semashko's Soviet model) and based on market principles and using private health insurance - American model. 
The health system currently used in our country is based on Semashko model. This means that the leading role in the health care system, including all functions within the system - regulator, supplier and buyer - is performed by the state. Speaking of the model of Nikolay Andreyevich Semashko, it is particularly relevant to the treatment and preventive infrastructure, the availability of specialized doctors and medical facilities. The basic principles of Soviet system health, founded by Semashko, are:

$\checkmark$ Centralized government subsidies for the protection of public health;

$\checkmark$ Free, accessible and equal treatment for everyone;

$\checkmark$ Establishment of sanitary facilities in the state health system;

$\checkmark$ Priority of pediatric and gynecological services;

$\checkmark$ Organization of activities aimed at prevention of diseases, etc.

The Soviet model was based on the principle "from everyone in line with his/her financial capabilities to all according to their material needs" [3].

\section{Key health indicators in Azerbaijan.}

As a result of the reforms carried out in the Republic of Azerbaijan, the key indicators of the health system of the country have improved. According to the State Statistics Committee, the average life expectancy in Azerbaijan in 2018 has increased from 73.6 to 75.8 in comparison with 2010. According to the Committee, the maternal mortality rate per 100,000 live births in the same period fell from 16 to 12 . However, although the average longevity and maternal mortality rates have improved from 2010 to 2018, under-five mortality rate per 1000 live births has remained almost constant. According to the Statistical Committee, under-five mortality rate per 1000 live births in 2018 was 13.1[4]. In Azerbaijan, under-five mortality rate per 1000 live births is considered to be the highest compared with some sample countries (Figure1) [5].

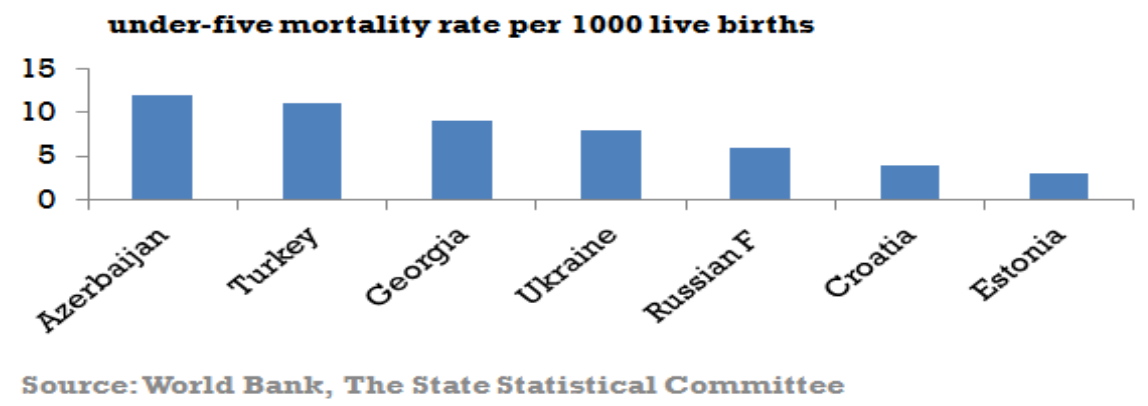

Fig. 1. Under-five mortality rate per 1000 live births

An analysis of life expectancy at birth shows that, although Azerbaijan is better than the Commonwealth of Independent States countries, it lags about 2-3 years behind some European countries, including Croatia, Estonia and neighboring Turkey.

Analysis of other data shows that the number of hospital beds from 756 in 2010 diminished to 563 by the beginning of 2019 , and the number of hospital beds for the same period as a result of reforms to optimize the performance of health care providers in order to increase efficiency and productivity decreased from 67,000 to 44,000 . The use of hospital resources has been increased by combining certain health providers and reducing the number of beds.

Based on international comparisons, Azerbaijan has a sufficient number of beds and hospitals, and the number of beds is comparable to that of the sample countries (Figure 2).

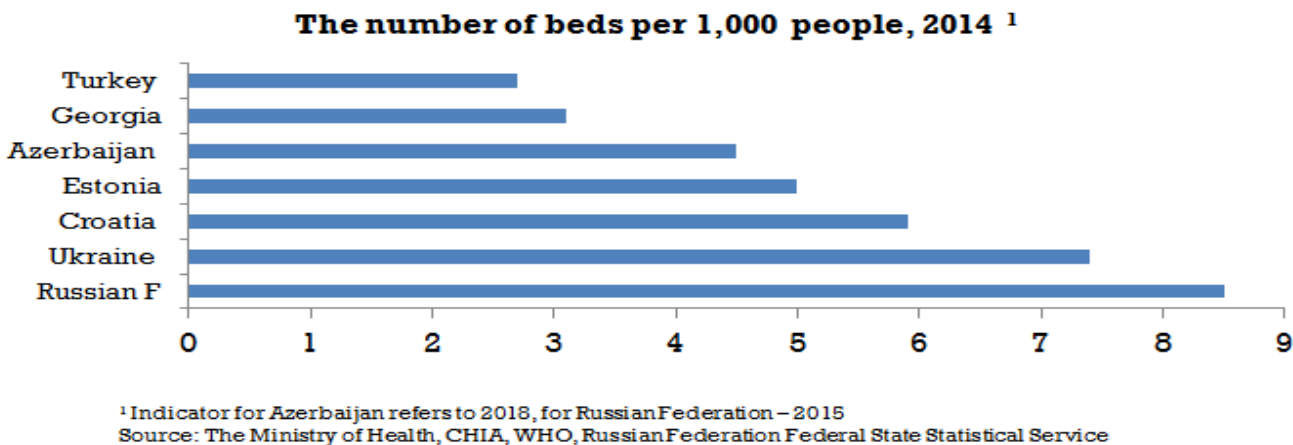

Fig. 2. The number of beds per 1000 people, 2014 
Assessment of a network of public hospitals shows that resources are not distributed equally between the regions. In absolute terms, by the beginning of 2019, 31\% of all hospitals, $45 \%$ of bed places, and $67 \%$ of physicians were in Baku city and Absheron economic region. Taking into account the per capita index, the number of bed places and hospitals per capita in certain areas is much higher than in others. For example, in Baku and Ganja, the number of doctors per 1000 population is 9.5 and 3.5, respectively. By contrast the number of doctors per 1,000 people in Sheki and Dashkesan is 1.8 and 0.6, respectively. As for the bed places, the number of beds per 1,000 people in Baku and Ganja is 8.1 and 6.5 respectively. In Sheki and Dashkesan, the number of bed places per 1,000 people is 3.7 and 3.1, respectively.

On the one hand, inefficient distribution of resources across the country, on the other hand, factors such as the high density of hospitals, the long distance between hospitals, the significant share of small rural hospitals, and the length of hospital stay is associated with a decline in the efficiency of health care providers.

The average hospital stay in Azerbaijan is twice higher than international practice of using beds effectively. Patients spent an average of 10 bed days in Azerbaijan. In most countries of Organization of Economic Cooperation and Development (OECD), the average number of hospital bed days is 5-7 days.

\section{Health system financing.}

Health development in the Republic of Azerbaijan, provision of population with medical care in line with world standards is one of the priorities of socio-economic policy in the country.

According to World Bank research, overall health expenditures in Azerbaijan are moderate to the level of income in the country, but the health care system is largely funded by out-of-pocket payments. For example, in 2018, out-of-pocket payments accounted for $79 \%$ of health care costs in Azerbaijan [6]. According to the calculations of the above-mentioned financial institution (taking into account the figures for 2016), the share of current health expenditure (out-of-pocket expenditure included) as a percentage to GDP in Azerbaijan is comparable to that of the sample countries and neighboring countries. Refer to World Bank the share of healthcare expenditures in GDP in Azerbaijan was higher than in Estonia, Ukraine, Russia and Turkey. However, the main problem of the system is the high share of pocket payments by Azerbaijani citizens (Figure 3) [7].

The share of health expenditure in GDP, 2016

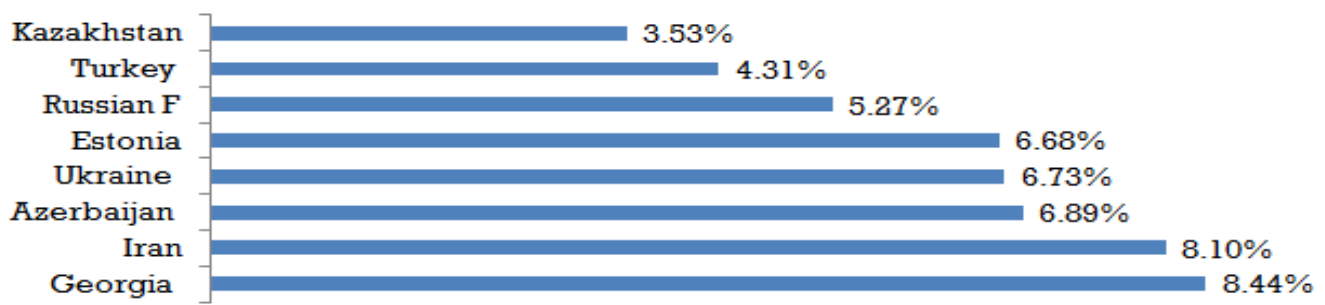

Source:World Bank

\section{Fig. 3. The share of health expenditure in GDP, 2016}

According to the World Health Organization (hereinafter referred to as WHO), out-of-pocket payments (OOPs) are defined as direct payments made by individuals to health care providers at the time of service delivery and use. This excludes any prepayment for health services, for example in the form of taxes or specific insurance premiums or contributions and, where possible, net of any reimbursements to the individual who made the payments.

In recent years, a number of countries have begun to implement health care reform and targeted policies to reduce out-of-pocket payments.

The main coverage of policies adopted in the area is the abolition of user fees and charges in public health facilities, exemption of specific population groups such as the poor and vulnerable, pregnant women and children from official payments, delivering a range of health services such as maternal and child care from official payments and deliver them free of chrage.

As noted in the WHO recommendations, the implementation of such strategies need political support, decision-making and proper preparation. User fee abolition and exemption can have a large impact on both demand and supply of health services. They likely increase the demand for services which 
subsequently affects the workload of health workers. On supply side, they can have drastic impact on the income of public health facilities. Unless substitutive sources for user fee revenues are not found, health service availability, quality, and supply of medical products will suffer and deteriorate.

For this reason, the effective implementation of the proposed strategies has a major commitment to finding alternative sources for financing a number of health services. Identification of new sources of funding is an important factor in terms of preventing side effects such as restricting access to health care services, lowering the quality of services, and declining supply, which could result from cancellation of payments in public health facilities [8].

According to a report by the WHO published in 2018 and comparisons between 24 OECD countries, $1 \%$ to $9 \%$ of households in Europe have been hit by poverty and therefore resorted out-ofpocket payments. Between $1 \%$ and $17 \%$ of households were forced to spend large amounts on health care, thus not meeting their minimum requirements for food, housing and heating. According to the report, high health care costs are among the more than $20 \%$ of the poor and occur during outpatient visits. Thus, pocket payments among European countries accounted for $22 \%$ of total health care costs. The lowest rate among the analyzed countries was in France where out-of-pocket payments account for $7 \%$ of health care costs. In Germany, this figure was at $12 \%$ level, $14 \%$ in the United Kingdom and 23\% in Estonia (Figure4) [9].

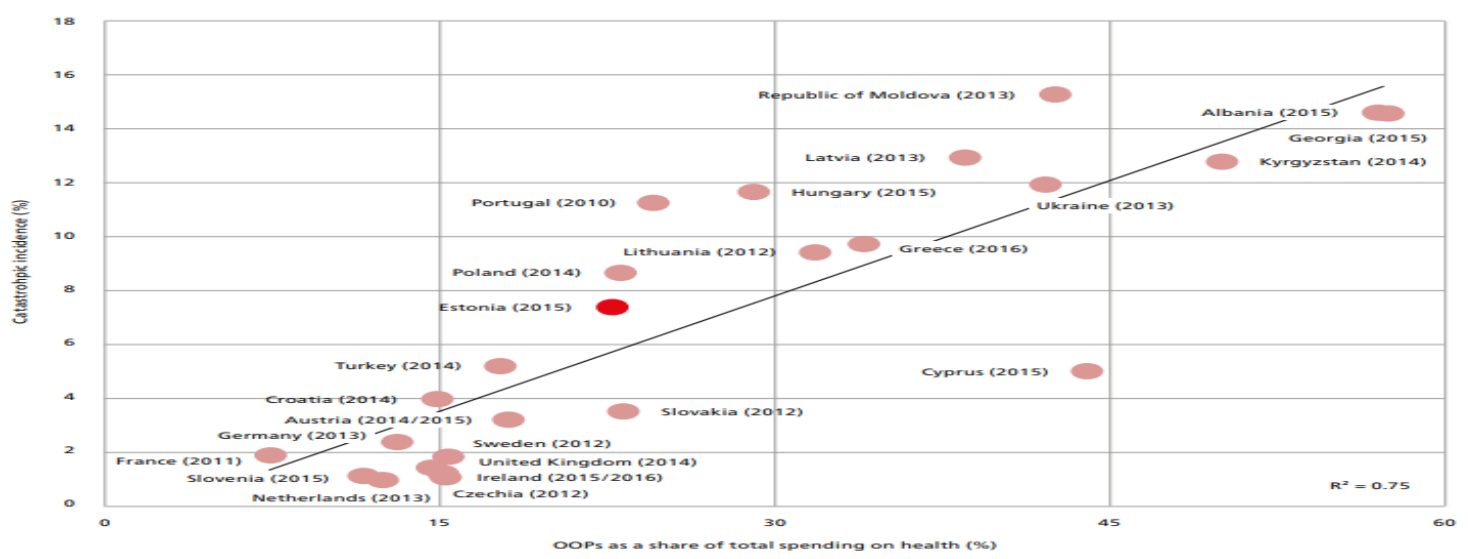

Fig. 4. OOPs as a share of total spending on health (\%), source: official page of WHO

Application of compulsory health insurance in Azerbaijan.

By adoption of the Law on Medical Insurance in 1999, establishment of the State Agency for Compulsory Medical Insurance under the Cabinet of Ministers of the Republic of Azerbaijan in 2007, the Concept of Health Insurance System Reform and Application of Compulsory Health Insurance in 2008 and finally by the Decree of the President of the Republic of Azerbaijan dated November 29, 2016 it was decided to implement compulsory health insurance as a pilot project in administrative areas of Mingachevir, Yevlakh and Aghdash districts.

The main goal of compulsory health insurance, which is a large-scale social project, is to protect the public from financial risks related to health while ensuring the sustainability of health care financing and access to health services. As mentioned above, the implementation of compulsory health insurance has been launched in the country since January 2017 as a pilot project. The main objectives of the pilot program were to test the health insurance system and gain important experience in this area, as well as the implementation of such important issues as the effectiveness of medical facilities. During the pilot project on compulsory health insurance, certain tools were used to improve public health services:

$\checkmark$ By providing autonomy to health facilities it was started to govern them at the regional level. The new management structure allowed for quick decision-making on human resources issues, as well as investment and allocation of resources.

$\checkmark$ Payments to health care providers were made on the basis of a new payment mechanism. This has encouraged health care providers to increase their productivity.

$\checkmark$ Medical workers' salaries were increased.

$\checkmark$ Participation of health workers in professional training both in the country and abroad.

$\checkmark$ By 2018 The State Agency for Compulsory Medical Insurance has established the "Legal Territory Management Association" (TABIB), a legal entity that includes public health facilities in the country, including medical institutions, research institutes, medical centers in Baku and regions. 
Subordinated to "Legal Territory Management Association" (TABİB), the application of compulsory health insurance in the health care system has spurred institutional changes, the organization of health services, and the improvement of the quality of health services.

During the pilot period, a number of tools were used to improve health care services: abolition of informal payments and use of private health services to pay for deficiencies. A modified payment mechanism was also used to stimulate physicians' activities and reduced sleep duration was applied.

As a result of these changes, the productivity of the workforce has doubled, and the total use of the services has increased by 27\% [10]. In addition, public health expenditures in Mingachevir increased, and total expenditures (including current and capital expenditures) remained at the same level of 15 million manats as compared to previous periods. The increase in funding from public funds was offset by a reduction in pocket expenses. In other words, unofficial funding has been replaced by official financing. In total, more than 370,000 people in the pilot areas used the base envelope of compulsory health insurance for the population and internally displaced persons (IDPs). As a whole, in pilot areas 2 state hospitals, 7 primary health care providers, 1 clinic and 1 tuberculosis clinic are involved in compulsory health insurance system. The basic envelope of compulsory health insurance includes 1829 medical services. During the period of the project, no insurance premium was collected from the public for three years.

For comparison, it is reasonable to look at the mechanism of applying compulsory health insurance, which was launched in Kazakhstan from September 1, 2019, as a pilot project in Karaganda region. As in our country, the system is expected to be launched in Kazakhstan from 2020 onwards. Selection of the Karaganda region as a pilot region is related to ensuring that all medical facilities here have full access to complex medical information system. A comprehensive medical information system is a process that includes the creation of a comprehensive electronic database of all patient information, diagnoses and medications and procedures written on them. In this regard, the implementation of the project in this region was considered technically feasible.

From September 1, 2019, Kazakhstan has allocated 2.3 billion tenge, or about 6 million USD, from the Kazakh state budget to implement a pilot project of health insurance covering more than 175,000 people. Allocated funds are mainly aimed at preventive examination, early prophylaxis of cardiovascular diseases, treatment of diseases such as diabetes, glaucoma, viral hepatitis, as well as medical rehabilitation, which is important in the field of medicine. Compared to Azerbaijan, in general, Mingachevir, Yevlakh and Agdash districts spent over 13.6 million AZN or \$ 8 million USD from the state budget in 2018 to provide compulsory health insurance services to more than 370,000 registered residents.

As part of the pilot project, 549,000 workers in the Karaganda region made insurance payments under compulsory health insurance. According to the Ministry of Health of Kazakhstan, the amount paid by workers amounted to 15.4 billion tenge, or \$ 39 million USD [11]. It should be noted that during the implementation of the project by the persons registered in the pilot areas in our country, no insurance premium was collected from the population during 3 years.

In 20174351 thousand manat was spent on increasing the salaries of medical workers in pilot areas in Azerbaijan, and 5221 thousand manat in 2018 relatively. The total salary fund of medical providers subordinated to the Compulsory Medical Insurance Agency amounted to 14143 thousand manat in 2017 and 16404 thousand manat in 2018, including incentive bonuses and bonuses to medical workers' salaries. The salaries of medical workers increased by 1.8 times in 2018 compared to 2016.

From January 1, 2020, the implementation of compulsory health insurance will cover 14 regions in the first quarter, 20 regions in the second quarter, 17 regions in the third quarter, and Baku, Sumgait and Absheron districts in the fourth quarter.

According to the Law of the Republic of Azerbaijan "On health insurance", which will come into force throughout the country by 2020 , the envelope of compulsory health insurance services will consist of two parts: basic and additional. According to the State Agency for Compulsory Medical Insurance, the basic part of the services envelope is to include primary health care, emergency and emergency medical care, and specialized medical care. As noted, the basic envelope of compulsory health insurance includes 1829 medical services.

It is envisaged that the use of the base unit will be paid at the expense of the state budget for the entire population of the country. Annual payment from the state budget for each citizen was decided to establish at the level of 29 AZN for the use of basic part of compulsory health insurance.

The use of specialized medical care, which is part of additional part of health insurance, is foreseen with the payment of compulsory health insurance. An additional part of the service envelope includes doctor's examination, laboratory diagnostics, surgical operations, care for the patient's needs 
and other medical services. At the same time, the state budget provides for the insurance of vulnerable groups, including children, students, pensioners, and people receiving social benefits and targeted state social assistance, which account for $45 \%$ of the Azerbaijani population.

Since these groups do not work and have no source of income, there is a need to meet their insurance premiums by the state. Thus, the health insurance of persons under the age of 18 is very important for timely meeting their medical needs and for the healthy upbringing of future generations. Protecting the health of children is of particular importance to the state, as healthy children mean a healthy future and a healthy workforce. It is also expected that child health insurance will lead to a reduction in health care costs in the future from the point of view of their health. Because of the lack of employment opportunities and income sources, there is a need for state-funded students to get a job. Pensioners, who make up about $13 \%$ of the population, have more medical needs than other groups, suffer from chronic illnesses, state health insurance of pensioners is of particular importance to their social protection and timely access to health care services and the increase in medical costs essential for purchase. Compulsory health insurance for hired workers and employers depending on the industry stipujlated to set at the level of $2 \%$ and $1 \%$ respectively, for other citizens 120 AZN per annum.

Research results. As a result of the research, the key health indicators have been analyzed at the level of different countries, especially Azerbaijan indicators have been examined. The process of implementation of compulsory health insurance as a pilot project in Azerbaijan has been explored and strong and weak parts were defined.

Conclusions. In general, the introduction of the health insurance mechanism allowed for the targeted collection and differentiation of financial resources. Thus, health insurance is considered to be one of the main mechanisms for the effective financing of public health services and increasing accessibility and quality of health services, attracting additional resources in this area and ensuring the public's interests. In addition, the development of the health care system should not only be formally limited to the system of compulsory public health insurance and should be taken into account, including a comprehensive approach to the issue, including fundamental changes in the funding mechanisms of health care providers and competition between insurance and health care providers.

Also, based on the mechanism of compulsory health insurance that has been introduced in pilot areas in the country and the results from this process, a number of proposals have been put forward to apply the best practices in the health insurance system being established in our country and conceptually taking into account national values, social and economic aspects:

- increase the effectiveness and sustainability, as well as increase the productivity of medical personnel should be executed in parallel with increase in salaries and elimination of illegal payments;

- implementation of optimization in the structure of health care providers in order to increase economic efficiency;

- implementation of a new competency management model.

\section{REFERENCES}

1. В.В. Гришин. Модели системы обязательного медицинского страхования. Финансы. 1996.

2. Afsar Akal and Roy Harvey: The Role of Health Insurance and Community Financing in Funding Immunization in Developing Countries, 2001

3. О.В.Ганин, С.В.Мещерякова: Правовые основы медицинского страхования граждан Российской Федерации, 2014

4. Official publications of The State Comittiee of Statistics of Azerbaijan Republic, social economic development publication, 2018

5. Trends in maternal mortality: 2020 to 2017, estimates by WHO, UNICEF, UNFPA, World Bank Group and the United Nations Population Division

6. Materials of "Human Development Forum in Azerbaijan", World Bank, 19-21 December, 2018, Baku

7. Information portal of World Bank - https://data.worldbank.org/indicator/sp.dyn.le00.in

8. Out-of-pocket payments, user fees and catastrophic expenditure, WHO

9. Public spending on health: a closer look at global trends, WHO, 2018

10. Official web page of the State Agency of Compulsory Health Insurance of the Republic of Azerbaijan www.its.gov.az

11. The Ministry of Health of Republic of Kazakhstan, official web page 